11 Ibid. S. 78.

12 Ibid. S. 79.

13 Ibid. S. 102.

14 Ibid. S. 71.

15 Ibid. S. 120.

DOI: 10.31168/2619-0869.2020.3.11

\begin{abstract}
«Искусство ли выше жизни?»: к проблеме сущности и существования (на материале повести В. Паскова «Баллада о Георге Хениге»)

Наталья Александровна Лунькова, Институт славяноведения Российской академии наук, Москва, Российская Федерация; e-mail: lunkova_n@mail.ru
\end{abstract}

Ключевые слова: экзистенциализм, Ясперс, онтология, болгарская литература, болгарская проза

\title{
"Is art more important than life?": on the issue of essence and existence (An analysis of "A Ballad for Georg Henig" by V. Paskov)
}

Natalia A. Lunkova, Institute of Slavic Studies, Russian Academy of Sciences, Moscow, Russian Federation; e-mail: lunkova_n@mail.ru

Keywords: existentialism, Jaspers, ontology, Bulgarian literature, Bulgarian prose

Творческий акт есть дерзновенный прорыв за пределы этого мира, к миру красоты.

Николай Бердяев

Условия развития личности в современную кризисную эпоху не могут не заставлять нас обращаться к вопросам человеческого бытия. Такие его категории, как сущность 
и существование, а также проблема их корреляции наиболее полно исследованы в философрии экзистенциализма. В качестве объекта для настоящего анализа была выбрана повесть «Баллада о Георге Хениге» (1987) болгарского писателя Виктора Паскова (1949-2009), предметом же рассмотрения стала проблема соотношения сущности и существования, их связи с искусством как особой духовной фрормой освоения действительности.

Методологической основой работы послужила онтологическая концепция К. Ясперса. В фрилософрии немецкого экзистенциалиста одним из определяющих понятий является пограничная ситуация (впервые термин введен в работе «Разум и экзистенция» (Vernunft und Existenz, 1935)), под которой подразумевается такой вид ситуации (пространства взаимодействия человека и действительности), где индивид бессилен что-либо изменить. $\mathrm{K}$ пограничным ситуациям относятся смерть, борьба, вина, страдание, зависимость от случайности. Именно они способствуют переходу личности от неподлинного бытия к подлинному, заставляя ее переживать трагический опыт. Благодаря пограничным ситуациям повседневное, обыденное бытие наполняется иным содержанием, раскрывает истинное предназначение человека. В пограничной ситуации, «перед лицом фризической, моральной или интеллектуальной гибели [...], в «безмотивной неудовлетворенности существованием» [...] сквозь предметное просвечивает и прорывается иной план бытия - «экзистенция» (Existenz), т.е. ноуменальный мир свободной воли, человеческая самость, внеположная всему предметному» ${ }^{1}$.

«Баллада о Георге Хениге» - история о старом скрипичном мастере, представителе знаменитой чешской династии, который волей судьбы в начале XX в. попал в Софию, где основал свою школу, добился известности (на его «скрипках играли по всей Европе»²), но впоследствии был забыт учениками. Сосредоточенные на славе и богатстве, они фиксировали свою причастность к миру как к наличному бытию 
(показательны описания пространства их мастерских, например: «Стены просторного помещения украшали новые дипломы на глянцевой бумаге, подтверждающие высокое мастерство владельца. [...] Все здесь говорило, просто кричало об успехе - яркое, блестящее, хвастливое» ${ }^{3}$.).

Сопоставление рассказчиком локусов мастерских Франтишека и Ванды - учеников Хенига - с бедным подвалом«пещерой» старика, где «пахло старостью, замшелостью, гнилью, смертью ${ }^{4}$, подчеркивает контраст между отношением героев к «бытию-в-мире». Их ценностные картины мира диаметрально противоположны. Чуждый материальному благополучию, Хениг был целиком отдан единственному делу своей жизни - созданию музыкальных инструментов. Он с осуждением относится к потребительскому отношению к искусству и с негодованием воспринимает деятельность учеников: «Жалько, что я учил вас добри стари ремеслу. Ничего не научил Георг Хениг, очень жаль. Не научил, как мастер работает не для деньги, не для клиент [здесь и далее курсив мой - H.Л.]. Работает, когда ничего не имеет [...] Релесло больше сали велики мастер. Ремесло сами велики на свете, и мастер счастливи, когда работает» ${ }^{5}$.

Для Хенига вещный уровень бытия не имел значения. Он считал поистине богатыми лишь тех, кто по-настоящему верен музыке, и старался передать мудрость и жизненный опыт рассказчику — «царю, мальки царю Виктору» ${ }^{6}$, который, повзрослев, специально возвращается в прошлое, чтобы осмыслить свое место в мире. И в самом начале повести признается: «Скорее это рассказ обо мне. Потому что я почти забыл, кто же я, в сущности, такой...».

Выросший в небогатой семье, герой неоднократно подчеркивает, что все обитателей его родного квартала жили очень бедно. Разочарованные в таком существовании, сходящие с ума или спивающиеся от невозможности вырваться из нищеты, соседи рассказчика и его родители, подобно ученикам 
Хенига, тоже оценивают себя преимущественно в категориях наличного бытия. Вот почему отец героя так стремится осуществить мечту своей жены о буфете - показателе богатства, залоге семейного благополучия: «Иметь буфет в то время было почти то же, что построить трехэтажную дачу с бассейном в наши дни» ${ }^{7}$. Почти обезумев, он перестает ходить на репетиции в театре и вместо бытия-в-искусстве выбирает бытие-в-мире, целиком посвящая себя изготовлению буфета и воспринимая это как доказательство своего права на лучшее существование: «Я больше не дурак и не бедный. [...] Знаешь, что ценится в этом мире? Вот это! Посмотри на него!.. Хорошенько на него посмотри, вот что ты упустил когда-то, мастер Хениг!»8 Можно было бы сказать, что будет с множеством затейливых ящичков - настоящее произведение искусства, однако он создавался ради утилитарного использования - и потому предельно предметен. Если и допустить, что подобное изготовление мебели - искусство, то только такое, где форма становится «в конечном итоге техникой, конструкция - расчетом» ${ }^{9}$, и в таком неподлинном виде не может "делать ощутимой трансценденцию», показывать человеку, «что есть Бог и что есть он сам» ${ }^{10}$.

Противоположное отношение к бытию символически описано в создании последней скрипки мастера. Предощущение смерти, которое становится моментом наивысшей творческой активности Хенига, - пример воздействия на человека той самой пограничной ситуации, которая «пробуждает субъект к экзистенции через радикальное потрясение его существования» ${ }^{11}$. Переживание неотвратимости ухода наделяет пожилого мастера небывалой жизненной энергией, благодаря которой он изготавливает шедевр всей своей жизни - виолу д'аморе, скрипку для Бога: «Георг Хениг словно впал в экстаз. Движения его стали быстры и уверенны. Со стороны ощущение было такое, словно он действует по чьей-то воле, таким затуманенным был его взгляд, такими 
точными - движения, таким странным внутреннил свеmол было озарено его лицо» ${ }^{12}$. Таким образом, через переживание пограничной ситуации человек может постичь свое предназначение, наполнить жизнь новым смыслом и преобразовать собственное бытие.

Подводя предварительный итог нашему исследованию, нужно отметить, что в «Балладе о Георге Хениге» именно через отношение к искусству «проверяется» подлинность бытия человека, который реализует в нем свою способность экзистировать. «Если уничтожен мир, прославлению которого служило искусство, то возникает вопрос, где же созидающий обнаружит подлинное бытие, которое дремлет, но должно благодаря ему обрести сознание и раскрытие. Искусства сегодня как бы бичуются существованиел; нет алтаря, у которого они могли бы обрести покой, прийти в себя, наполниться содержанием» ${ }^{13}$.

\section{Примечания}

1 Аверинцев С.C. Ясперс // Новая философская энциклопедия [Сайт]. URL: https://iphlib.ru/library?el=\&a=d\&c=newphilenc\&d=\&rl=1\&href= http:\%2f\%2f3625.html (дата обращения 30.08.2020)

2 Пасков В. Баллада о Георге Хениге // Пасков В. Детские истории взрослого человека. М., 2018. С. 85.

3 Там же. С. 145.

4 Там же. С. 113.

5 Там же. С. 221.

6 Там же. С. 93.

7 Там же. 123.

8 Там же. С. 159.

9 Ясперс K. Духовная ситуация времени // Ясперс $K$. Смысл и назначение истории. М., 1991. С. 368.

10 Там же.

11 Ясперс К. Философия. Книга первая. Философское ориентирование в мире. М., 2012. С. 76.

12 Пасков В. Баллада о Георге Хениге. С. 203.

13 Ясперс K. Духовная ситуация времени. С. 367. 